\title{
Erratum to: Screen Time, Other Sedentary Behaviours, and Obesity Risk in Adults: a Review of Reviews
}

\author{
Stuart J. H. Biddle ${ }^{1,2}$ • Enrique García Bengoechea ${ }^{1,3}$ - Zeljko Pedisic ${ }^{1}$. \\ Jason Bennie ${ }^{1,2} \cdot$ Ineke Vergeer $^{1,2}$. Glen Wiesner ${ }^{1}$
}

Published online: 21 June 2017

(C) Springer Science+Business Media, LLC 2017

\section{Erratum to: Curr Obes Rep (2017) 6:134-147}

DOI 10.1007/s13679-017-0256-9

In the original version of this article, which published in Current Obesity Reports, Volume 6, Issue 2, June 2017, the second author's name was captured incorrectly. Enrique's family name is García Bengoechea, which means Enrique García Bengoechea is correct on the title page. For citations, it should come out as García Bengoechea E.

The name provided above is now correct.

The online version of the original article can be found at http://dx.doi.org/ 10.1007/s13679-017-0256-9

Stuart J. H. Biddle

stuart.biddle@usq.edu.au

Enrique García Bengoechea

enrique.garcia@mail.mcgill.ca

Zeljko Pedisic

zeljko.pedisic@vu.edu.au

Jason Bennie

jason.bennie@usq.edu.au

Ineke Vergeer

ineke.vergeer@usq.edu.au

Glen Wiesner

glen.wiesner@vu.edu.au

1 Institute of Sport, Exercise and Active Living, Victoria University, Melbourne, Australia

2 Institute for Resilient Regions, University of Southern Queensland, Central, Springfield, Australia

3 McGill University, Montreal, Canada 